\title{
Study of morphometric and ruminal parameters in santa inês sheep fed spineless cactus (Opuntia ficus-indica, MILL)
}

[Estudo dos parâmetros morfométricos e ruminais em ovinos Santa Inês alimentados com cactus sem espinhos (Opuntia ficus-indica, MILL)]

\author{
J.M. Porto Filho ${ }^{1}$, R.G. Costa ${ }^{l^{*}}$, N.L. Ribeiro², R.R. Guerra ${ }^{1}$, J.S. Oliveiral, G.R. Beltrão ${ }^{2}$ \\ ${ }^{1}$ Aluno de pós-graduação - Universidade Federal da Paraíba/CCA - Areia, PB \\ ${ }^{2}$ Universidade Federal da Paraíba, Bananeiras, PB
}

\begin{abstract}
The present study aimed to morphometrically evaluate the ruminal mucosa and ruminal fluid characteristics of Santa Inês sheep fed different levels of spineless cactus as a replacement for Tifton grass hay. A total of 32 intact male Santa Inês sheep, approximately 180 days old and with a mean weight of $32.0 \pm 1.6 \mathrm{~kg}$, were studied in a completely randomized design with four treatments and eight replicates. The morphometric measurements evaluated in the ruminal epithelium (papilla height and surface area) were significantly affected $(\mathrm{P}<0.05)$ by supplementation of the diet with spineless cactus, and these effects showed increasing linear trends. Evaluations of the ruminal fluid also showed a significant increasing linear effect $(\mathrm{P}<0.05)$ for ammonia and a quadratic effect for microbial protein. The inclusion of spineless cactus in the sheep diet affects the ruminal epithelium morphology, including the papilla height and surface area, and favors the absorption process in the rumen. The diet containing higher levels of spineless cactus led to maximum microbial protein production. These results characterize spineless cactus as a feasible alternative for feeding sheep during periods of drought, when the typical food source is scarce.
\end{abstract}

Keywords: ruminal mucosa, ruminal papillae, microbial protein, volatile fatty acids

\section{RESUMO}

O presente estudo teve como objetivo avaliar morfometricamente a mucosa ruminal e as características do líquido ruminal de ovinos Santa Inês alimentados com diferentes níveis de palma forrageira como substituta do feno de capim-Tifton. Um total de 32 ovinos, machos inteiros, da raça Santa Inês, com

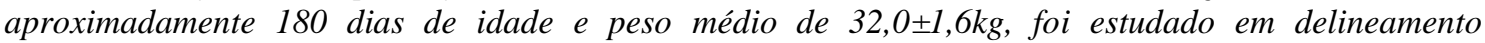
inteiramente ao acaso, com quatro tratamentos e oito repetições. As medidas morfométricas avaliadas no epitélio ruminal (altura e área superficial da papila) foram significativamente afetadas $(P<0,05)$ pela suplementação da dieta com palma forrageira, e esses efeitos mostraram tendências lineares crescentes. As avaliações do fluido ruminal também mostraram um efeito linear crescente significativo $(P<0,05)$ para a amônia e um efeito quadrático para a proteína microbiana. A inclusão de palma forrageira na dieta de ovinos afeta a morfologia do epitélio ruminal, englobando a altura e a área da papila, $e$ favorece o processo de absorção no rúmen. A dieta contendo níveis mais altos de palma forrageira levou à produção máxima de proteína microbiana. Esses resultados caracterizam a palma forrageira como uma alternativa viável para a alimentação de ovelhas durante períodos de seca, quando a fonte típica de alimento é escassa.

Palavras-chave: ácidos graxos voláteis, mucosa ruminal, papila ruminal, proteina microbiana

Recebido em 4 de janeiro de 2018

Aceito em 4 de dezembro de 2018

*Autor para correspondência (corresponding author)

E-mail: betogermano@hotmail.com 


\section{INTRODUCTION}

Sheep production in Brazil is an activity of great social and economic importance, especially for the Northeastern region, and plays a crucial role in the development of the region, where $52 \%$ of the Brazilian national herd, that is, 17.7 million sheep (Conservation..., 2009), is concentrated. In this region, the dry season represents a large obstacle for animal production due to food scarcity and decreases in the nutritional value of the forages, leading to the need to confine animals during periods of drought, which elevates the cost of production. To mitigate the effect of food scarcity during these periods of drought, the identification of alternative forages is essential. These are characterized by good development in semiarid regions and ability to meet the nutrient demands of the herds and favor meat production.

Spineless cactus (genus Opuntia, subfamily Opuntioideae, family Cactaceae) is a xerophile producing approximately 200-300 species, growing mainly in arid and semiarid zones (Stintzing and Carle, 2005). It is a Mexican cactus that is large-scale farmed in Northeastern Brazil and was introduced to Pernambuco State, Brazil, circa 1880 via seeds imported from Texas, United States. Three different spineless cactus types are observed in Northeastern Brazil: a) giant - Opuntia fícus indica, b) round (Opuntia sp), and c) small - (Nopalea cochenillifera) (Taiz and Zeiger, 1998).

Within the Brazilian semiarid scenario, spineless cactus (Opuntia ficus indica Mill) is a highpotential forage resource, as this succulent forage is important for the herds, especially during prolonged dry periods, and it meets most of the water requirements of the animals (Barbosa et al., 2017) in addition to providing palatable feed. Spineless cactus is also considered a mucilagerich feed, with significant mineral levels, mainly calcium (2.0 to $5.7 \%$ ), potassium (1.5 to $2.58 \%$ ), magnesium (1.3 to $1.7 \%$ ), and phosphorus ( 0.1 to $0.6 \%$ ) (Wanderley et al., 2002). It even has high levels of non fiber carbohydrates and low levels of neutral detergent fibers, making it an important feed alternative in semiarid regions (Barbosa et al., 2017).

The gastrointestinal epithelium is responsible for various functions, including nutrient absorption, which is related to the development of ruminal papillae and intestinal villi (Xu et al., 2009). According to Martens et al. (2012), sheep initially fed diets with low energy content and/or low concentrate content experience changes in ruminal mucosa, especially in papilla size and in adaptation to changes in ruminal parameters, such as $\mathrm{pH}$, fatty acid concentration, and osmotic pressure.

Because absorption of the volatile fatty acids (VFAs) at the ruminal level is performed by ruminal papillae and because an increase in such structures increases the ruminal absorptive capacity, attempts to identify the papillary development that will maximize nutrient use, via diet manipulation, is a determining factor in the development of research, making this approach common in ruminant nutrition studies. Thus, the present study aimed to evaluate morphological alterations in the ruminal epithelium as well as to study the ruminal fermentation parameters in Santa Inês sheep fed different levels of spineless cactus to replace Tifton grass hay (Cynodon ssp.).

\section{MATERIALS AND METHODS}

The experiment was conducted at the Goat and Sheep Production Sector of the Federal University of Paraíba (Universidade Federal da Paraíba - UFPB), located in Bananeiras, Paraíba State, Brazil, microregion of Brejo Paraibano, $6^{\circ} 45^{\prime} 00^{\prime \prime} \mathrm{S}$ latitude and $35^{\circ} 38^{\prime} 00^{\prime \prime} \mathrm{W}$ longitude, at an altitude of $520 \mathrm{~m}$ above sea level. This study was approved by the Animal Ethics Committee of the Federal University of Paraiba (UFPB), Brazil (protocol no. 2305/14).

A total of 32 intact male Santa Inês sheep, approximately 180 days old and with a mean body weight of $32.0 \mathrm{~kg} \pm 1.6$, were used. The experimental design used was a completely randomized design with four treatments and eight replicates. The animals were kept in a covered barn in collective stalls $\left(3.6 \mathrm{~m}^{2}\right)$ equipped with food and water troughs, with two animals occupying each stall.

The treatments comprised diets with a 50:50 forage to concentrate ratio, with different levels of Tifton grass hay being replaced with spineless cactus (Opuntia ficus indica, MILL); that is, the forage feeds contained $0 \%, 33.3,66.7$, and $100 \%$ 
of spineless cactus on a dry matter basis (Table 1). The diets were formulated to be isoproteic and isocaloric to obtain weight gains of $0.300 \mathrm{~kg} / \mathrm{animal} / \mathrm{day}$, according to the NRC (Nutrient..., 2007). The diets were offered in two daily meals to allow approximately $20 \%$ leftovers.

The experiment comprised 56 days of confinement, preceded by a 14-day period for adaptation to the diets. The animals were slaughtered when they obtained a weight of $32 \mathrm{~kg}$ or after a minimum of 42 days of confinement. The animals were slaughtered after fasting from solids (16 hours); at this time, they were weighed again to obtain the live weight at slaughter.
A $1-\mathrm{cm}^{2}$ fragment was harvested from the ruminal wall in the cranial region of the ventral rumen for the morphometric measurements of the ruminal epithelium of each slaughtered animal. The number count of the ruminal papillae was evaluated using a stereoscopic loupe at $6 x$ magnification. After the papillae had been counted, 12 random papillae from each fragment were selected. Height (from the papilla apex until its insertion point), width (within the middle region of the papillae in the latero-lateral direction), and surface area were obtained, where the latter measurement was obtained by multiplying the height by width, according to the method adapted by Bittar et al. (2009) and Costa et al. (2008).

Table 1. Proportion and chemical composition of the experimental diet with different inclusion levels of spineless cactus

\begin{tabular}{|c|c|c|c|c|}
\hline \multirow{2}{*}{ Ingredients $\left(\mathrm{g} \mathrm{kg}^{-1}\right)$} & \multicolumn{4}{|c|}{ Inclusion levels (\%) } \\
\hline & 0.0 & 16.7 & 33.3 & 50.0 \\
\hline Tifton hay & 500 & 333 & 167 & 00.0 \\
\hline Spineless Cactus & 0.00 & 167 & 333 & 500 \\
\hline Ground corn & 270 & 270 & 270 & 270 \\
\hline Soybean meal & 120 & 118 & 117 & 116 \\
\hline Wheat bran & 90.0 & 90.0 & 90.0 & 90.0 \\
\hline Urea & 0.00 & 2.00 & 3.00 & 4.00 \\
\hline Mineral supplement ${ }^{1}$ & 15.0 & 15.0 & 15.0 & 15.0 \\
\hline Calciticlimestone & 5.00 & 5.00 & 5.00 & 5.00 \\
\hline \multicolumn{5}{|c|}{ Chemical composition } \\
\hline Dry matter, DM ( $\mathrm{g} \mathrm{kg}^{-1}$ as fed) & 948 & 364 & 226 & 164 \\
\hline Crude protein. $\mathrm{CP}\left(\mathrm{g} \mathrm{kg}^{-1} \mathrm{DM}\right)$ & 135 & 136 & 135 & 134 \\
\hline Ethereal extract. $\mathrm{EE}\left(\mathrm{g} \mathrm{kg}^{-1} \mathrm{DM}\right)$ & 51.1 & 53.7 & 56.4 & 59.1 \\
\hline Neutral detergent fiber. NDF $\left(\mathrm{g} \mathrm{kg}^{-1} \mathrm{DM}\right)$ & 660 & 577 & 494 & 411 \\
\hline Fiber in acid detergent. FAD ( $\left.\mathrm{g} \mathrm{kg}^{-1} \mathrm{DM}\right)$ & 280 & 240 & 201 & 162 \\
\hline Total Carbohydrates. TC ( $\left.\mathrm{g} \mathrm{kg}^{-1} \mathrm{DM}\right)$ & 716 & 713 & 710 & 707 \\
\hline Non-fibrous carbohydrates. NFC $\left(\mathrm{g} \mathrm{kg}^{-1} \mathrm{DM}\right)$ & 107 & 187 & 264 & 347 \\
\hline Metabolizable energy, ME (Mcal/kg DM) & 2.46 & 2.51 & 2.56 & 2.61 \\
\hline Calcium & 6.28 & 9.27 & 12.3 & 15.3 \\
\hline Phosphorus & 5.35 & 5.49 & 5.63 & 2.80 \\
\hline
\end{tabular}

${ }^{1}$ Mineral supplement: Ca 140.0g; P 65.0g; S 15.0g; Mg 15.0g; Zn 3,500.0mg; Mn 3,000.0; I 60.0mg; Se 10.0mg; Co $100.0 \mathrm{mg}$; Vit A 50,000.0IU/kg; Fluorine (max) $650.0 \mathrm{mg}$.

The ruminal fluid was collected in a 2-ml Eppendorf tube soon after animal slaughter and was frozen in freezers at $-20{ }^{\circ} \mathrm{C}$. The ruminal ammonia concentration was evaluated using the Chaney and Marbach colorimetric method (Chaney and Marbach, 1962), and the microbial protein concentration was evaluated using the Bradford method (Bradford et al., 1976).
The volatile fatty acids (lactic, acetic, propionic, and butyric) were identified and quantified using high performance liquid chromatography (HPLC) in a SHIMADZU chromatograph, SPD10A VP model, coupled to an Ultra Violet Detector (UV) using a wavelength of $210 \mathrm{~nm}$ in a C18 column (reverse phase). 
The data resulting from the macroscopic analyses and ruminal parameters were compiled, and the statistical analysis was conducted via regression analysis at $5 \%$ probability, using the PROC GML procedure of the SAS program (SAS..., 2009).

\section{RESULTS AND DISCUSSION}

The morphometric, height, and surface area measurements evaluated in the ruminal epithelium were significantly affected $(\mathrm{P}<0.05)$ by supplementing spineless cactus in the diet and showed an increasing linear trend (Table 2).

Table 2. Morphometric measurements of the ruminal mucosa of the sheep fed with different levels of spineless cactus

\begin{tabular}{lccccccc}
\hline \multirow{2}{*}{ Variables } & \multicolumn{4}{c}{ Inclusion levels $(\%)$} & \multicolumn{2}{c}{ P value } & \multirow{2}{*}{ MSE } \\
\cline { 2 - 7 } & 0.0 & 16.7 & 33.3 & 50.0 & $\mathrm{~L}$ & $\mathrm{Q}$ & \\
\hline Papillae $\left(\mathrm{N}^{\circ} / \mathrm{cm}^{2}\right)$ & 92.8 & 79.5 & 76.4 & 96.9 & 0.843 & 0.087 & 28.07 \\
Thickness $(\mathrm{mm})$ & 1.60 & 1.84 & 1.79 & 1.99 & 0.074 & 0.892 & 0.38 \\
Height $(\mathrm{mm})$ & 2.60 & 3.15 & 3.36 & 5.22 & $0.001^{1}$ & 0.119 & 1.18 \\
Surface area $\left(\mathrm{mm}^{2}\right)$ & 4.29 & 5.82 & 6.37 & 10.53 & $0.001^{2}$ & 0.250 & 3.20 \\
\hline
\end{tabular}

Mean Standard error $=$ MSE

${ }^{1} \mathrm{Y}=2.3717+0.0485 \mathrm{x}\left(\mathrm{R}^{2}=0.84\right)$

${ }^{2} \mathrm{Y}=3.8961+0.1125 \mathrm{x}\left(\mathrm{R}^{2}=0.88\right)$

The mean height and surface area were $3.58 \mathrm{~mm}$ and $6.75 \mathrm{~mm}^{2}$, respectively. The data demonstrated that with the increasing amount of spineless cactus in the Santa Inês sheep diet to replace Tifton hay, an increase in papilla height and surface area in the rumen was present, most likely stimulated by the elevation in non fiber carbohydrates in the diet, which increased by $225 \%$ compared to the treatment without spineless cactus.

Several studies have shown that an increase in the ingestion of rapidly fermentable carbohydrates stimulates the development of ruminal papillae in calves (Zitnan et al., 1998 and 2005; Lesmeister and Heinrichs, 2005), growing cattle (Zitnan et al., 2003), goats (Shen et al., 2004; Wang et al., 2009), and sheep (Odongo et al., 2006). The results of those studies reinforce the results obtained in the present study, where sheep diets were supplemented with spineless cactus.

Diets with high levels of rapidly fermentable carbohydrates tend to produce high levels of volatile fatty acids (Pereira and Armentano, 2000), which stimulate papilla development. In this context, the papillae increase their absorptive capacity, increasing their length, width, and consequently, their total area in an attempt to absorb higher amounts of volatile fatty acids, seeking to avoid, for example, conditions of ruminal acidosis (Melo et al., 2013).
When evaluating the histomorphometry ruminal of sheep fed spineless cactus, Neiva et al. (2006) (60.0, 47.5 and $34.8 \%$ ) had ruminal papillae more developed than animals that did not receive fodder in their diet.

Ruminal fermentation in sheep fed highconcentrate content causes increased VFA production and reduces the ammonia concentration (Askar et al., 2008). According to Costa et al. (2008), the VFA type present in the ruminal content can affect the growth response of the epithelial cells, and the effects of solid food ingestion on ruminal growth can depend more on the final products of fermentation and other humoral factors that stimulate rumen motility. However, when the produced VFAs exceed the absorption capacity of the ruminal papillae, they accumulate in the rumen, leading to a decrease in $\mathrm{pH}$, and epithelial injury can occur in the rumen (Wang et al., 2009). Therefore, the results of the current study suggest that the VFA production was favorable to the growth of the ruminal epithelium with the increasing level of supplementation of the diets with spineless cactus.

In evaluating the ruminal fluid from sheep fed diets in which the Tifton hay was replaced with spineless cactus, a linear increase was observed in ammonia concentration, and a quadratic increase was observed in the presence of microbial protein (Table 3); these effects were significant $(\mathrm{P}<0.05)$. 
Table 3. Evaluation of the ruminal fluid of sheep fed with increasing levels of spineless cactus

\begin{tabular}{lcccccc}
\hline \multirow{2}{*}{ Variables } & \multicolumn{3}{c}{ Inclusion levels $(\%)$} & \multicolumn{3}{c}{ P value } \\
\cline { 2 - 7 } & 0.0 & 16.7 & 33.3 & 50.0 & $\mathrm{~L}$ & $\mathrm{Q}$ \\
\hline Ammonia $(\mathrm{mg} / \mathrm{dl})$ & 12.7 & 26.5 & 19.7 & 27.9 & $0.037^{1}$ & 0.495 \\
Microbial protein $(\mathrm{mg} / \mathrm{l})$ & 590 & 470 & 411 & 712 & 0.459 & $0.019^{2}$ \\
Lactic acid $(\mu / \mathrm{ml})$ & 568 & 392 & 567 & 310 & 0.067 & 0.516 \\
Acetate $(\mu / \mathrm{ml})$ & 239 & 224 & 217 & 228 & 0.516 & 0.345 \\
Propionate $(\mu / \mathrm{ml})$ & 86.6 & 82.3 & 84.0 & 80.0 & 0.106 & 0.957 \\
Butyrate $(\mu / \mathrm{ml})$ & 14.6 & 13.1 & 15.2 & 15.4 & 0.157 & 0.226 \\
\hline${ }^{1} \mathrm{Y}=15.871+0.2331 \times\left(\mathrm{R}^{2}=0.52\right)$ & & & & & &
\end{tabular}

${ }^{2} \mathrm{Y}=499.63+1.8449 \mathrm{x}\left(\mathrm{R}^{2}=0.88\right)$

According to Van Soest (1994), ruminal ammonia originates from non protein nitrogen in the diet, from degradation of the actual dietary protein, and from recycling via saliva or diffusion through the ruminal wall. Furthermore, ammonia can be removed by the incorporation of microbial protein via passage to the posterior tract or ruminal absorption. According to Sannes et al. (2002), an insufficient ruminal ammonia concentration can depress the fiber digestion function and microbial growth, as the bacterial population uses ammonia to grow, and the amount of ammonia used to synthesize the bacterial protein depends on the availability of energy provided by the fermentation of carbohydrates.

The ammonia concentration in the ruminal fluid increased from 12.7 to $27.9 \mathrm{mg} / \mathrm{dl}$ with increasing spineless cactus and urea levels in the diet. The increase in ruminal ammonia concentration may be due to the increase in urea concentration nonprotein nitrogen (NNP) in the sheep diets when the spineless cactus content increased in the diet, leading to higher ammonia production from the urea. Higher soluble protein or non-protein nitrogen $(\mathrm{N})$ levels tend to increase the total degraded protein content in the rumen and, consequently, increase the ammonia and amino acid levels in the ruminal fluid (Russell et al., 1992).

Previous research indicates that hay replacement by forage palm reduces $\mathrm{pH}$ and $\mathrm{NH} 3$ concentration in the ruminal fluid in goats and sheep (Bispo et al., 2007; Vieira et al., 2008).

A significant quadratic effect $(\mathrm{P}<0.05)$ was observed on the microbial protein concentration with the increasing replacement of Tifton hay with spineless cactus (Table 3). In the intermediate diets (16.7 and $33.3 \%$ inclusion of the spineless cactus), the microbial protein concentration decreased and, soon after, showed a significant increase when $100 \%$ of the Tifton grass was replaced with spineless cactus.

This decrease in protein in the intermediate diets may have occurred due to a lack of synchronization in the energy:protein ratio. That is, variation in the protein sources and energy content of foods has a great effect on microbial protein synthesis (Westwood et al., 1998). The synchronized use of the protein and carbohydrates in the feed is necessary for optimal microbial growth and protein synthesis, thereby benefitting ruminal digestibility (Clark et al., 1992) and protein and energy efficiency (Hoover and Stokes, 1991). The increase in the amount of spineless cactus (16.7 and 33.3\%) led to an increase in the amount of non fiber carbohydrates, and urea also increased (Table 1), both of which are rapidly degradable. In contrast, protein from the diet with the Tifton grass hay undergoes slow degradation, leading to a lack of energy sufficient for protein degradation and conversion of ammonia into microbial protein.

The same effect was not observed with the diet with $50 \%$ inclusion of the spineless cactus. Due to the low amount of protein from the spineless cactus, urea, which was rapidly degradable, was the main substrate for protein synthesis. Additionally, rapid energy was supplied in this diet by fermentation of the 'non-fiber carbohydrate (NFC) from the spineless cactus. Thus, adequate synchronization was assumed to occur between the supply of energy and nitrogen for the ruminal microorganisms, considering the high concentration of soluble carbohydrates in the spineless cactus, which facilitates incorporation of supplementary nitrogen into microbial protein. 
Volatile fatty acids produced by rumen fermentation are extremely important, and supply approximately $70 \%$ of the energy used by ruminants (France and Dijkstra, 2005). The individual proportions between VFAs are of particular interest because different VFAs arise according to the variation in substrate ingestion and bacterial populations. Furthermore, VFAs have distinct metabolic fates (Dijkstra et al., 2012). Among the products of rumen fermentation, acetate is the most oxidized, and its formation determines the maximum yield in ATP for bacteria (Kozloski, 2009). In particular, propionic acid is a substrate for gluconeogenesis and is the main source of glucose in ruminants.

No depreciation was observed in the acetate:propionate ratio, which remained, on average, 2.76:1, thereby demonstrating a favorable environment for ruminal metabolism (Table 3). According to Teixeira and Teixeira (2001), the ideal acetate:propionate proportion is between $2: 1$ and $4: 1$.

This proportion may have occurred due to the assumption that by increasing spineless cactus in the diets, no decline would occur in the $\mathrm{pH}$ because, according to Valadares Filho and Pina (2006), pH exerts a selective pressure on microorganisms that are sensitive to changes in $\mathrm{pH}$ during the adaptation to diets with high concentrate levels. That is, when $\mathrm{pH}$ decreases, propionate-producing and acid-resistant gramnegative bacteria increase, whereas acetateproducing gram-positive bacteria, present in higher numbers in grazing animals, decrease (Russell and Strobel, 1989).

Thus, replacing Tifton hay with spineless cactus improved the ruminal environment, demonstrated a positive effect on the epithelium as well as on the ammonia concentrations and protein concentrations, and did not affect volatile fatty acid production.

\section{CONCLUSION}

The inclusion of $50 \%$ of spineless cactus affects the morphology of the ruminal mucosa of sheep and the papilla height and surface area, thereby favoring the absorption process in the rumen. This level of inclusion does not interfere with volatile fatty acid production, maintains the acetate:propionate ratio in the ideal proportion, and achieves higher microbial protein production.

\section{REFERENCES}

ASKAR，A.R.; GUADA，J.A.; GONZÁLEZ, J.M. et al. Rumen digestion and microbial protein synthesis by growing lambs fed highconcentrate diets: effects of cereal processing and animal age. Anim. Feed Sci. Technol., v.142, p.292-305, 2008.

BARBOSA, M.L.; SILVA, T.G.F.; ZOLNIER, S. et al. Association of morphological and water factor with irrigated forage cactus yield. Rev. Bras. Eng. Agric. Ambient., v.121, p.600-605, 2017.

BISPO, S.V.; FERREIRA, M.A.; VÉRAS, A.S.C. et al. Spineless cactus in replacement of elephantgrass hay. Effect on intake, apparent digestibility and ruminal fermentation characteristics in sheep. Rev. Bras. Zootec., v.36, p.1902-1909, 2007.

BITTAR, C.M.M.; FERREIRA, L.S.; SANTOS, F.A.P. et al. Performance and ruminal development of dairy calves fed starter concentrate with different physical forms. Rev. Bras. Zootec., v.38, p.1561-1567, 2009.

BRADFORD, M.M. A rapid and sensitive method for the quantitation of microgram quantities of protein utilizing the principle of protein-dye binding. Anal. Biochem., v.64, p.136-141, 1976.

CHANEY, A.L.; MARBACH, E.P. Modified reagents for determination of urea and ammonia. Clin. Chem., v.8, p.130-132, 1962.

CLARK, J.H.; KLUSMEYER, T.H.; CAMERON, M.R. Microbial protein synthesis and flows of nitrogen fractions to the duodenum of dairy cows. J. Dairy Sci., v.75, p.2304-2323, 1992.

CONSERVATION and sustainable utilization for food and agriculture. [Roma]: FAO, 2009. Available in: <http// http://www.fao.org/docrep/013/i1500e/Brazil.pdf >. Accessed in: 21 Jun. 2017

COSTA, S.F.; PEREIRA, M.N.; MELO, L.Q. et al. Lactate, propionate and, butyrate induced morphological alterations on calf ruminal mucosa and epidermis - I Histologycals aspects. Arq. Bras. Med. Vet. Zootec., v.60, p.1-9, 2008. 
DIJKSTRA, J.; ELLIS, J.L.; KEBREAB, E. et al. Ruminal $\mathrm{pH}$ regulation and nutritional consequences of low pH. Anim. Feed Sci. Technol., v.172, p.22-33, 2012.

FRANCE, J.; DIJKSTRA, J. Volatile fatty acid production. In. J. DIJKSTRA, J.M. FORBES, J. FRANCE (Eds.). Quantitative aspects of ruminant digestion and metabolism. Wallingford: CAB International, 2005.p.157175.

HOOVER, W.H.; STOKES, S.R. Balancing carbohydrates and proteins for optimum rumen microbial yield. J. Dairy Sci., v.74, p.3630-3644, 1991.

KOZLOSKI, G.V. (Ed.). Bioquímica dos ruminantes. Santa Maria: UFSM, 2009. 214p.

LESMEISTER, K.E.; HEINRICHS, A.J. Effects of adding extra molasses to a texturized calf starter on rumen development, growth characteristics, and blood parameters in neonatal dairy calves. J. Dairy Sci., v.88, p.411-418, 2005.

MARTENS, H.; RABBANI, I.; SHEN, Z. et al. Changes in rumen absorption processes during transition. Anim. Feed Sci. Technol., v.172, p.95102, 2012.

MELO, L.Q.; COSTA, S.F.; LOPES, F. et al. Rumen morphometrics and the effect of digesta $\mathrm{pH}$ and volume on volatile fatty acid absorption. Anim. Sci. J., v.91, p.1775-1783, 2013

NEIVA, M.G.S.; MOTA, D.L.; BATISTA, V.A.M. et al. Mucous membrane of the rumen of ovines, fed with spineless, forrage cactus or palm (Barbary fig) (Opuntia ficus indica Mil): histochemical study by means of light microscopy, Int. J. Morphol., v.24, p.723-728, 2006.

NUTRIENT requeriments of small ruminants. 7.ed. Washington: National Academic Press, 2007. 408p.

ODONGO, N.E.; ALZAHAL, O.; LINDINGER, M.I. et al. Effects of mild heat stress and grain challenge on acid-base balance and rumen tissue histology in lambs. J. Anim. Sci., v.84, p.447455,2006
PEREIRA, M.N.; ARMENTANO, L.E. Partial replacement of forage with nonforage fiber sources in lactating cow diets. II. Digestion and rumen function. J. Dairy Sci., v.83, p.2876-2887, 2000.

RUSSELL, J.B.; O'CONNOR, J.D.; FOX, D.G. et al. A net carbohydrate and protein system for evaluating cattle diets: I. Ruminal fermentation. J. Anim Sci., v.70, p.3551-3561, 1992.

RUSSELL, J.B.; STROBEL, H.J. Effect of ionophores on ruminal fermentation. Appl. Environ. Microbiol., v.55, p.1-6, 1989.

SANNES, R.; MESSMAN, A.; VAGNONI, D.B. Form of rumen-degradable carbohydrate and nitrogen on microbial protein synthesis and protein efficiency of dairy cows. J. Dairy Sci., v.85, p.900-908, 2002.

SAS/STAT: user's guide. Version 9.2. Cary: SAS Institute, 2009.

SHEN, Z., SEYFERT, H.M., LÖHRKE, B. et al. An energy-rich diet causes ruminal papillae proliferation associated with more IGF type 1 receptors and increased plasma IGF-1 concentrations in young goats. J. Nutr., v.134, p.11-17, 2004

STINTZING, F.C.; CARLE, R. Cactus stems (Opuntia spp.): a review on their chemistry, technology, and uses. Mol. Nutr. Food Res., v.49, p.175-194, 2005

TAIZ, L.; ZEIGER, E. (Eds.). Plant physiology. Sunderland: Sinauer Associates, 1998. 792p.

TEIXEIRA, J.; TEIXEIRA, L. Princípios de nutrição de bovinos leiteiros. Lavras: UFLA/FAEP, 2001. 245p. (Textos acadêmicos).

VALADARES FILHO, S.C.; PINA, D.S. Fermentação ruminal. In: BERCHIELLE, T.T.; PIRES, A.V.; OLIVEIRA, S.G. (Eds.). Nutrição de ruminantes. Jaboticabal: Funep, 2006. 583p.

VAN SOEST, P.J. (Ed.). Nutritional ecology of the ruminant. Ithaca, New York: Cornell University Press, 1994. 476p.

VIEIRA, E.L., BATISTA, A.M.V.; GUIM, A. et al. Effects of hay inclusion on intake, in vivo nutrient utilization and ruminal fermentation of goats fed spineless cactus (Opuntia fícus-indica Mill) based diets. Anim. Feed Sci. Technol., v.141, p.199-208, 2008. 
WANDERLEY, W.L.; FERREIRA, M.D.A.; ANDRADE, D.D. et al. Replacement of forage cactus (Opuntia fícus indica MILL). Rev. Bras. Zootec., v.31, p.273-281, 2002.

WANG, Y.H.; XU, M.; WANG, F.N. et al. Effect of dietary starch on rumen and small intestine morphology and digesta $\mathrm{pH}$ in goats. Livest. Sci., v.122, p.48-52, 2009.

WESTWOOD, C.T.; LEAN, I.J.; KELLAWAY, R.C. Indications and implications for testing of milk urea in dairy cattle: a quantitative review. Part 2. Effect of dietary protein on reproductive performance. N. Z. Vet. J., v.46, p.123-130, 1998.
XU, J.; LAMOUILLE, S.; DERYNCK, R. TGF$\beta$ - induced epithelial to mesenchymal transition. Cell Res., v.19, p.156-172, 2009.

ZITNAN, R.; KUHLA, S.; NURNBERG, K. et al. Influence of the diet on the morphology of ruminal and intestinal mucosa and on intestinal carbohydrase levels in cattle. Vet. Med., v.48, p.177-182, 2003.

ZITNAN, R.; KUHLA, S.; SANFTLEBEN, P. et $a l$. Diet induced ruminal papillae development in neonatal calves not correlating with rumen butyrate. Vet. Med., v.50, p.472-479, 2005.

ŽITNAN, R.; VOIGT, J.; SCHÖNHUSEN, U. et al. Influence of dietary concentrate to forage ratio on the development of rumen mucosa in calves. Arch. Anim. Nutr., v.51, p.279-291, 1998. 